\title{
Pelayanan Jasa Sopir Gojek Online Kepada Konsumen Pada Aplikasi Gojek Online Cabang Purwakarta Dalam Perspektif Ekonomi Syariah
}

\author{
Shanti Karistawati ${ }^{1}$, Rina Nurhayati ${ }^{2}$, Siti Rohmat ${ }^{3}$ \\ 1,2,3 STIES Indonesia Purwakarta \\ 1shantykariesta@gmail.com \\ ${ }^{2}$ inamaza212@gmail.com \\ 35itirohmat38@gmail.com
}

\begin{abstract}
Abstrak Artikel ini membahas tentang alat transportasi saat ini bukan hanya sekedar untuk alat perpindahan atau mobilitas saja, namun untuk efisiensi waktu dan meminimalisir kemacetan. Tolak ukur keberhasilan sebuah perusahaan transportasi dilihat dari bagaimana proses pemberian pelayanan terbaik untuk konsumen. Perusahaan yang berhasil mempromosikan layanannya baik produk maupun jasanya kepada konsumen dengan kualitas pelayanan yang memuaskan akan mendapatkan brand dan nilai lebih yang baik dimata konsumen. Penelitian ini dilakukan bertujuan untuk mengetahui kualitas pelayanan terhadap konsumen aplikasi Gojek Online dan untuk mengetahui kualitas pelayanan sopir dalam pandangan Perspektif Islam. Metode pendekatan lapangan (field research) bagi peneliti merupakan metode penelitian yang tepat dalam penelitian ini. Sehingga penelitian ini juga bisa disebut penelitian kasus atau study kasus (case study) dengan pendekatan deskriptif kualitatif. Dari hasil penelitian tersebut dapat disimpulkan bahwa perusahaan Gojek Online memiliki standar operasional prosedur dalam melayani konsumen baik itu terkait dengan penampilan sopir masih belum sesuai. Jika ditinjau dari cara bisnis menurut sifat Rosullulah yaitu terkait dengan sifat Shiddiq, Amanah, Thabligh, Fathanah masih belum sepenuhnya sesuai.
\end{abstract}

Kata kunci : Gojek Online, Sopir, Pelayanan, Jasa, Konsumen

Abstract This article discusses the current means of transportation not only for moving equipment or mobility, but for time efficiency and to minimize congestion. Benchmarks of the success of a transportation company can be seen from how the process of providing the best service for consumers. Companies that successfully promote their services both products and services to consumers with satisfying service quality will get a brand and better value in the eyes of consumers. This study was conducted aiming to determine the quality of service to consumers Gojek Online applications and to determine the quality of driver services in the perspective of Islamic Perspective. The field research method for researchers is the right research method in this research. So this research can also be called a case study or case study with a qualitative descriptive approach. From the results of this study it can be concluded that the Gojek Online company has standard operating procedures in serving consumers both related to the appearance of the driver is still not appropriate. When viewed from the way of business according to the nature of Rosullulah which is related to the nature of Shiddiq, Amanah, Thabligh, Fathanah is still not entirely appropriate.

Key words : Gojek Online, Driver, Services, Services, Consumers

\section{PENDAHULUAN}

Dunia bisnis merupakan dunia yang paling ramai dibicarakan pada berbagai forum, baik pada level nasional maupun internasional (Mujariyah \& Ruzikna, 2016). Dalam rangka pembangunan Negara kita masa kini dan masa yang akan datang, maka faktor pengangkutan memegang peranan yang sangat penting. Barang-barang harus diangkut dari suatu daerah ke daerah lainnya, agar barang itu dapat memenuhi kebutuhan hidup manusia. Demikian pula orang sering bepergian dari suatu daerah ke daerah lain guna untuk bekerja, berkunjung ataupun hanya untuk berekreasi. Kemudian kita lihat pula, alat 


\section{EKSISBANK Vol. 4 No. 1 Juni 2020}

transfortasi berbagai macam jenis yang ada di masyarakat seperti kereta api, bus, pesawat, taxi, kapal laut, ojek dan lain sebagainya (Buchari Alma, 2007).

Alat transportasi pada masa ini yang dibutuhkan bukan hanya sekedar untuk alat perpindahan atau mobilitas saja, namun untuk efisiensi waktu dan meminimalisir kemacetan yang terjadi, selain itu memberikan pelayanan terbaik terhadap konsumen sebagai tolak ukur keberhasilan sebuah perusahaan. Perusahaan yang berhasil memasarkan produk/jasanya pada konsumen menggunakan pelayanan yang memuaskan menerima merk yang baik dimata konsumen. Pelayanan yang dimaksud termasuk asal pelayanan memberikan produk/jasa, pelayanan saat memberikan jasa, pelayanan atas resiko yang terjadi ketika memberikan jasa dan pelayanan lain sebagainya (Assauri, 2015).

Perusahaan transportasi salah satunya adalah PT. Gojek Online Indonesia. Perusahaan yang telah berhasil memasarkan produk / jasanya kepada konsumen dengan pelayanan yang memuaskan mendapatkan brand yang baik dimata konsumen. Timbul beberapa masalah yang dirasakan oleh pengguna Gojek Online dalam sisi pelayananya, salah satunya yaitu keluhan para pengguna Gojek Online terhadap fasilitas safety berkendara seperti helm dan jaket yang digunakan memiliki bau yang kurang enak sehingga menimbulkan ketidaknyamanan pada saat pengantaran. Keluhan yang dirasakan oleh pengguna aplikasi Gojek Online terhadap kurangnya respon para sopir untuk mengangkut para penumpang yang jarak tujuannya cukup jauh membuat banyak penumpang Gojek Online beralih pada transportasi lain, padahal banyak sopir Gojek Online yang berada disekitar lokasi pengangkutan. Masalah lainnya yang dirasakan oleh pengguna seperti waktu penjemputan penumpang yang lebih lama, tidak adanya jaminan resiko tindak kriminal, serta kehandalan sopir dalam membawa kendaraan. Dari banyaknya masalah yang terjadi, memberikan dampak negatif terhadap kepercayaan pelanggan sehingga memberikan efek menurunnya pemesanan jasa transportasi Gojek Online. Dalam hal ini kualitas pelayanan Gojek Online perlu ditingkatkan kembali untuk dapat tetap mempertahan dan menciptakan kepuasan para pelanggan. Sebagai seorang muslim dalam memberikan pelayanan harus berprinsip pada nilai-nilai syariah guna mewujudkan ketaqwaan sekaligus membuktikan konsistensi keimanan dalam menjalankan syariat Islam. Sikap pelayanan yang baik di dalam pandangan Perspektif Islam dijadikan tolak ukur dalam menilai kualitas pelayanan terhadap konsumen yaitu standardisasi syariah. Islam mensyari'atkan kepada manusia agar selalu terikat dengan hukum syara' dalam menjalankan setiap aktivitas ataupun memecahkan setiap masalah.

Dari latar belakang pemaparan diatas penulis tertarik ingin mengkaji lebih dalam lagi tuntuk meneliti kualitas pelayanan yang diterapkan oleh para sopir Gojek Online. Maka dari itu saya ingin membuat sebuah penelitian dengan judul "Pelayanan Jasa Sopir Gojek Online Kepada Konsumen Pada Aplikasi Gojek Cabang Purwakarta Dalam Perspektif Ekonomi Syariah".

Jasa atau layanan adalah tindakan atau kinerja apa pun yang dapat ditawarkan salah satu pihak kepada pihak lain yang pada dasarnya tidak berwujud dan tidak mengakibatkan kepemilikan apapun. Produksinya mungkin terkait atau tidak dengan produk fisik (Adam, 2015).

Menurut Kotler, jasa memiliki 4 ciri utama yang sangat mempengaruhi rancangan program pemasaran, yaitu:

1. Tidak Berwujud (Intangibility)

Jasa mempunyai sifat tak berwujud, karena tidak bisa dilihat, dirasakan, diraba, didengar atau dicium sebelum ada transaksi pembelian. Untuk mengurangi ketidakpastian, pembeli akan mencari tanda atau bukti dari mutu jasa tersebut. Pembeli akan mengambil kesimpulan mengenai mutu jasa dari tempat (place), manusia (people), peralatan (equipment), alat komunikasi (communication material), simbol-simbol (symbols), dan harga (price) yang mereka lihat.

2. Tidak Dapat Dipisahkan (Inseparability) Jasa-jasa umumnya diproduksi secara khusus dan dikonsumsi pada waktu yang bersamaan. Jika jasa diberikan oleh seseorang, maka orang tersebut merupakan bagian dari jasa tersebut. 


\section{EKSISBANK Vol. 4 No. 1 Juni 2020}

Client juga hadir pada saat jasa diberikan, interaksi penyedia client merupakan ciri khusus dari pemasaran jasa tersebut.

\section{Beraneka Ragam (Variability)}

Sering kali pembeli jasa menyadari akan keanekaragaman ini dan membicarakannya dengan yang lain sebelum memilih seorang penyedia jasa. Jasa itu sangat beraneka ragam, karena tergantung kepada penyedia jasa dan kapan serta dimana disediakan.

4. Tidak Tahan Lama (Perishability)

Jasa-jasa tidak dapat disimpan. Keadaan tidak tahan dari jasa-jasa bukanlah masalah jika permintaanya stabil, karena mudah untuk melakukan persiapan pelayanan sebelumnya. Jika permintaan terhadapnya berfluktuasi maka perusahaan jasa menghadapi masalah yang sulit.

Secara sederhana, pelayanan diartikan sebagai "proses pemenuhan kebutuhan melalui aktifitas orang lain secara langsung" (Tampi et al., 2016). Lebih luas, Pelayanan-pelayanan diartikan sebagai serangkaian kegiatan, karena itu ia merupakan proses. Sebagai proses, pelayanan berlangsung secara rutin dan berkesinambungan meliputi keseluruhan orang dalam masyarakat. Sebagai sebuah proses, layanan tidak dapat dipisahkan dengan manusia itu sendiri, untuk itu sifat pelayanan / jasa yang intangible sulit jika dipisahkan dari penyedia jasa itu sendiri (Hakim et al., 2018).

Kualitas pelayanan adalah totalitas fitur dan karakteristik produk atau jasa yang bergantung pada kemampuannya untuk memuaskan kebutuhan yang dinyatakan atau tersirat (Fajar Fahrudin \& Yulianti, 2015). Pengertian lain menyatakan bahwa kualitas pelayanan adalah sebagai tingkat keunggulan yang diharapkan dan pengendalian atas tingkat keunggulan tersebut untuk memenuhi keinginan pelanggan. Kualitas pelayanan sangat penting sebab kualitas pelayanan merupakan salah satu faktor yang meningkatkan kepuasan konsumen. Setiap perusahaan berlomba untuk menghasilkan kualitas pelayanan yang terbaik untuk konsumennya (Mutmainah \& Kamaluddin, 2019).
Kualitas pelayanan terdiri dari lima dimensi, meliputi (Djunaidi et al., 2006); (Rully Tri Indriastuti, 2010):

1. Keandalan, adalah kemampuan yang dapat diandalkan, akurat dan konsisten dalam mengerjakan jasa sesuai dengan yang diinginkan konsumen.

2. Tanggapan, adalah kemauan untuk membantu konsumen dan memberikan jasa dengan segera standar - standar yang digunakan harus disesuaikan dengan permintaan kecepatan respon yang diinginkan konsumen serta persepsi konsumen tentang kecepatan dan kesegeraan, dan bukannya didasarkan atas persepsi perusahaan.

3. Assurance, mencakup keandalan atau jaminan kompetensi, dapat dipercaya, kejujuran pemberi jasa, pemilikan kecakapan dan pengetahuan yang diperlukan untuk mengerjakan jasa, dan kredibilitas.

4. Empati, secara umum konsumen membutuhkan kemudahan akses, komunikasi yang mudah (baik), dan memiliki keinginan untuk dipahami kebutuhannya. Oleh karena itu, pengertian empati dapat mencakup kemudahan akses, komunikasi yang baik, dan pemahaman terhadapkonsumen.

5. Tangible, dapat mencakup penampilan fasilitas atau elemen- elemen fisikal, peralatan, personel, dan material-material komunikasi. Tujuannya adalah untuk memperkuat kesan tentang kualitas, kenyamanan dan keamanan dari jasa yang ditawarkan kepada konsumen.

Etika pelayanan adalah tentang kemampuan untuk membedakan antara yang benar dan yang salah serta melakukaan semua pelayanan dengan kualitas, integritas dan akuntabilitas yang tinggi. Etika pelayanan yang baik akan meningkatkan kepercayaan pelanggan kepada layanan yang diberikan. Etika pelayanan perspektif Islam adalah pelayanan yang ramah terhadap para wajib pajak dan perlakuan yang sama kepada masyarakat tidak cukup, selain itu juga perlakuan yang adil dan dipandang sebagai salah satu cara untuk menyelesaikan masalah sehingga dapat menghindari kesalahan (Wardana \& Ariyanto, 2016). 


\section{EKSISBANK Vol. 4 No. 1 Juni 2020}

Pengertian kualitas pelayanan tidak secara langsung dijumpai di dalam Al-Quran secara eksplisit, tetapi didasarkan pada konsep memberikan pelayanan yang baik kepada manusia itu telah diperintahkan oleh Allah SWT, dalil syareayah terdapat dalam Al-Quran.

Ada 4 (empat) hal yang menjadi kuci sukses dalam mengelola suatu bisnis dalam Perspektif Islam, agar mendapat nilai-nilai moral yang tinggi. Untuk memudahkan mengingat, kita singkat dengan SAFT, yaitu (Sula \& Kartajaya, 2006) :

\section{Shiddiq (Jujur)}

Jujur yaitu tidak pernah berdusta dalam melakukan suatu kegiatan transaksi. Jujur juga merupakan kesesuaian antar berita.

\section{Amanah}

Amanah yang berarti bertanggung jawab atas semua pkerjaan yang dilakukan

\section{Fhatanah (profesional)}

Fathanah disini yang berarti profesional, sopir Go-Jek berusaha bekerja dengan semaksimal dalam melakukan suatu pekerjaan mentaati peraturan perusahaan tidak melanggar.

4. Tabligh (kesopanan dan keramahan)

Tabligh artinya komunikatif dan argumentatif. Kesopanan dan keramahan merupakan inti dalam memberikan pelayanan.

Konsumen berasal dari bahasa asing (berkonsumen inggris), consumen dan consumer yang arti harfiahnya adalah pembeli. Pengertian lain dari konsumen sangat luas, beragam dan sangat terkait erat dengan tujuan seseorang membeli suatu produk isinya sebagai pengguna,yang diterjemahan dari kata user dari kata bahasa inggris. Pengertian dari konsumen adalah pemakai, pemirsa, dan masih banyak lagi (Syahbuddin, 2018).

Harapan konsumen untuk mencapai kepuasannya secara total dilihat dari: (Nuha, 2016); (Hosang et al., 2016):

1. Lebih baik (better) dalam artian meningkatnya kualitas jasa

2. Lebih cepat (Faster) dalam hal ini pelayanan yang didapatkan oleh konsumen lebih cepat.

3. Lebih baru (Newer) adanya pembaharuan dari produk atau jasa yang lebih lengkap.
4. Lebih Murah (Cheaper) harganya semakin murah.

5. Lebih sederhana (More Simple) fasilitas yang semakin mudah dan sederhana.

Adapun tujuan yang ingin dicapai oleh penulis dalam penulisan ini adalah untuk mengetahui kualitas pelayanan yang para sopir Gojek Online di purwakarta dan untuk mengetahui kualitas pelayanan sopir Gojek Online di Purwakarta dalam pandangan Perspektif Islam.

\section{METODE PENELITIAN}

Jenis penelitian ini adalah penelitian lapangan (field research) yaitu penelitian yang objeknya mengenai gejala-gejala atau peristiwa-peristiwa yang terjadi pada kelompok masyarakat. Sehingga penelitian ini juga bisa disebut penelitian kasus atau study kasus (case study) dengan pendekatan deskriptif kualitatif (Arikunto, 2013).

Penelitian kualitatif yaitu penelitian yang menghasilkan prosedur analisis yang tidak menggunakan prosedur analisis statistik atau cara kuantifikasi lainnya. Jelas bahwa pengertian ini mempertentangkan penelitian kualitatif dengan penelitian yang bernuansa kuantitatif yaitu dengan menonjolkan bahwa usaha kuantifikasi apapun tidak perlu digunakan pada penelitian kualitatif.

Teknik pengumpulan data merupakan cara yang dilakukan peneliti untuk mengungkap atau menjaring informasi dari responden sesuai lingkup penelitian. Berikut ini ada beberapa teknik pengumpulan data:

\section{A. Wawancara}

Penelitian ini menggunakan jenis wawancara terbuka dan terstruktur, arti dari wawancara terbuka itu sendiri adalah wawancara yang para subjeknya tahu bahwa mereka sedang diwawancarai dan mengetahui pula apa maksud dan tujuan wawancara itu (Moleong, 2017). Wawancara terstruktur adalah wawancara yang pewawancaranya menetapkan sendiri masalah da pertanyaanpertanyaan yang akan diajukan (Moleong, 2017). Penelitian ini dilakukan secara terstruktur dan terbuka, dimana yang diwawancarai baik sopir maupun konsumen 


\section{EKSISBANK Vol. 4 No. 1 Juni 2020}

Gojek Online telah mengetahui apa maksud dan tujuan pewawancara dan susunan pertanyaan telah disiapkan sesuai apa yang akan ditanyakan dan apa yang ingin didapatkan untuk dijadikan sumber data. Wawancara dilakukan kepada pihak yang terlibat, yaitu sopir dan konsumen Gojek Online. Waktu dan tempat dilakukan dalam wawancara ini adalah langsung datang kepada sopir dan konsumen sebagai narasumber langsung.

B. Observasi

Observasi yang dilakukan dalam penelitian ini adalah jenis observasi pasif (passive participation) adalah jenis obervasi yang dalam hal ini peneliti datang di tempat kegiatan orang yang diamati, tetapi tidak ikut terlibat dalam kegiatan tersebut (Sugiyono, 2017). Maka, dalam penelitian ini peneliti hanya mengamati dan observasi secara tidak langsung melalui media sosial dan mengamati bagaimana pelayanan yang dilakukan.

C. Dokumentasi

Dokumentasi merupakan salah satu bukti bahwa penulis benar melakukan penelitian. Dokumentasi penulis berupa foto, dan hasil dari wawancara. Dokumen yang didapat dari sini adalah mengenai standar layanan prosedur pihah Gojek Online. Dokumen mengenai daftar pertanyaan serta isi dari hasil wawancara.

Sumber data adalah subjek dari mana asal data penelitian itu diperoleh. Dalam melakukan penelitian ini data-data yang diperlukan diperoleh dari dua sumber yaitu:

A. Data Primer

Data primer adalah data yang dikumpulkan dan diolah sendiri oleh suatu organisasi atau perorangan langsung dari objeknya. Pengumpulan data tersebut dilakukan secara khusus untuk mengatasi masalah riset yang sedang diteliti. Sumber primer dalam penelitian ini di dapat dari hasil wawancara yang dilakukan terhadap 10 sopir Gojek Online dan 10 kosumen Gojek Online.

B. Data Sekunder

Data sekunder adalah data yang diperoleh dalam bentuk yang sudah jadi, sudah dikumpulkan dan diolah oleh pihak lain, biasanya sudah dalam bentuk publikasi. Data semacam ini sudah dikumpulkan pihak lain untuk tujuan tertentu yang bukan untuk keperluan riset yang sedang dilakukan peneliti saat ini secara spesifik (Hendryad, 2015). Sumber sekunder penelitian ini diperoleh dari data atau arsip buku-buku referensi, dan situs website.

Analisis data adalah proses mencari dan menyusun secara sistematis data yang diperoleh dari hasil wawancara, catatan lapangan, dan bahan-bahan lain, sehingga dapat mudah dipahami, dan temuannya dapat diinformasikan kepada orang lain (Sugiyono, 2017). Analisis data dalam penelitian kualitatif dilakukan sejak sebelum memasuki lapangan, selama di lapangan dan setelah selesai di lapangan. Aktivitas dalam analisis data, yaitu: data reduction, data display, dan conclusion drawing/verification (Sugiyono, 2017).

\section{A. Data Reduksi (Data Reduction)}

Menurut Milles dan Huberman, mereduksi data adalah merangkum, memilih hal-hal yang pokok, memfokuskan pada hal-hal yang penting, dicari tema dan polanya. Dengan demikian data yang telah direduksi akan memberikan gambaran yang lebih jelas, dan mempermudah peneliti untuk melakukan pengumpulan data selanjutnya dan mencarinya bila diperlukan sehingga disusun secara sistematis dan mudah dikendalikan.

B. Penyajian data (data display)

Setelah data direduksi maka langkah selanjutnya adalah mendisplaykan data yang dapat dilakukan dalam bentuk tabel, grafik, pictogram dan sejenisnya. Melalui penyajian data tersebut maka data terorganisasikan, tersusun dalam pola hubungan, sehingga akan semakin mudah dipahami dalam rangka memperoleh kesimpulan sebagai temuan penelitian.

C. Penarikan kesimpulan atau verifikasi (conclusion drawing/verification) Langkah ketiga dalam analisis data kualitatif menurut Miles dan Huberman adalah penarikan kesimpulan dan verifikasi. Kesimpulan awal yang dikemukakan masih bersifat sementara, 


\section{EKSISBANK Vol. 4 No. 1 Juni 2020}

dan akan berubah bila tidak ditemukan buktibukti yang kuat yang mendukung pada tahap pengumpulan data berikutnya. Tetapi apabila kesimpulan yang dikemukakakn pada tahap awal, didukung oleh bukti-bukti yang valid dan saat peneliti kembali ke lapangan mengumpulkan data, maka kesimpulan yang dikemukakan merupakan kesimpulan yang kredibel.

Keabsahan data dalam penelitian ini ditentukan dengan menggunakan kriteria kredibilitas. Untuk mendapatkan data yang relevan, maka peneliti melakukan pengecekan keabsahan data hasil penelitian dengan cara:

A. Perpanjangan Pengamatan

Dalam penelitian ini peneliti melakukan perpanjangan pengamatan, dengan kembali lagi ke lapangan untuk memastikan apakah data yang telah penulis peroleh sudah benar atau masih ada yang salah.

B. Ketekunan Pengamatan

Meningkatkan ketekunan berarti melakukan pengamatan secara lebih cermat dan berkesinambungan. Dengan cara tersebut maka kepastian data dan urutan peristiwa akan dapat direkam secara pasti dan sistematis (Sugiyono, 2017). Meningkatkan ketekunan itu ibarat kita mengecek soal- soal, atau makalah yang telah dikerjakan, apakah ada yang salah atau tidak. Dengan meningkatkan ketekunan itu, maka peneliti dapat melakukan pengecekan kembali apakah data yang telah ditemukan itu salah atau tidak. Demikian juga dengan meningkatkan ketekunan maka, peneliti dapat memberikan deskripsi data yang akurat dan sistematis tentang apa yang diamati (Sugiyono, 2017).

C. Triangulasi

Dalam penelitian ini menggunakan triangulasi sumber. Triangulasi sumber digunakan untuk pengecekan data tentang keabsahannya, membandingkan hasil wawancara dengan isi suatu dokumen dengan memanfaatkan berbagai sumber data informasi sebagai bahan pertimbangan. Dalam hal ini penulis membandingkan data hasil observasi dengan data hasil wawancara, dan juga membandingkan hasil wawancara dengan wawancara lainnya

\section{HASIL DAN PEMBAHASAN}

Hasil dari penelitian yang diteliti bahwa kualitas pelayanan yang terdapat pada Gojek Online di Purwakarta mempunyai standar layanan sebagai berikut (Ipul, 2019):

\section{A. Penampilan sopir}

1. Menggunakan jaket resmi Gojek Online

2. Warna jaket tidak pudar

3. Jaket tidak berbau / tercium wangi

4. Jaket tidak berlubang

5. Tidak ada bagian yang dipotongpada jaket (jaket tidak dimofdifikasi)

6. Helm standar SNI

7. Celana Panjang

8. Sepatu tertutup

\section{B. Kondisi Kendaraan}

1. Pijakan kaki untuk konsumen

2. Kaca spion dipasang

3. Lampu Utama Menyala

4. Lampu Sen Dapat digunakan

5. Knalpot standar dalam artian bukan mengeluarkan suara nyaring)

\section{Layanan Kepada Konsumen}

1. Ketika order berhasil diambil tidak perlu menghubungi penumpang untuk konfirmasi

2. Ketika sampai di lokasi penjemputan hendaknya mengirim sms atau telepon dengan mengatakan bahwa sopir telah mencapai lokasi penjemputan

3. Ketika bertemu dengan konsumen hendaknya menyapa konsumen dengan sapaan sopan seperti "Pak / Bu dengan (nama konsumen) ya?" dan "Tujuan ke (tujuan konsumen)?"

4. Foto sopir harus sesuai dengan informasi di aplikasi konsumen

5. Plat nomor kendaraan harus sesuai dengan informasi di aplikasi konsumen

6. Menawarkan masker kepada konsumen.

7. Menawarkan penutup rambut kepada konsumen

8. Helm yang digunakan arus helm resmi Gojek Online untuk konsumen.

9. Helm dalam keadaan bersih dan tidak berbau.

10. Pengait helm arus bekerja dengan baik.

11. Kaca helm dapat dibuka dan tutup 


\section{EKSISBANK Vol. 4 No. 1 Juni 2020}

12. Pijakan kaki siap digunakan konsumen

13. Tanyakan rute perjalanan yang biasa digunakan konsemen seperti "Biasanya lewat jalan mana Pak / Bu ?".

14. Selama dalam perjalanan tidak memulai pembicaraan yang tidak perlu kepada konsumen, kecuali menawarkan jas hujan atau menawarkan berhenti sejenak ketika hujan, ganti rute jika macet parah dan isi bensin.

15. Ketika telah sampai kepada pelanggan hendaknya mengucapkan terima kasih kepada pelanggan.

Kualitas pelayanan dalam Islam telah diatur diantaranya mengenai sifat Fathanah, sifat Tabligh, sifat Shidiq dan sifat Amanah. Kualitas pelayanan yang dilakukan oleh sopir Gojek Online dari hasil observasi dan wawancara menunjukan adanya kesesuaian dan ketidaksesuaian diantaranya:

1. Profesional (Fathanaah)

Fathanah disini yang berarti profesional, sopir Go-Jek berusaha bekerja dengan semaksimal dalam melakukan suatu pekerjaan mentaati peraturan perusahaan tidak melanggar. Seperti tertera dalam Alquran Surat Yusuf Ayat 55 :

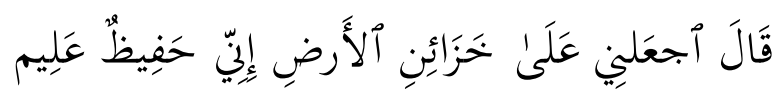
"Berkata Yusuf: "Jadikanlah aku bendaharawan negara (Mesir); sesungguhnya aku adalah orang yang pandai menjaga, lagi berpengetahuan".

Dalam Hadist Riwayat Bukhari Muslim dijelaskan:

$$
\text { بَلِّغُوا عَيَّن وَلَوْ آَيَةً (رواه البخارى ومسلم) }
$$

“Sampaikan walaupun satu ayat. "(H.R.

Bukhari Muslim)

Dalam pelayanan sopir Gojek Online tingkat profesionalisme tentang pelayanan yang dilakukan masih minim hal ini terkait dengan adanya beberapa standar dalam pelayanan yang seharusnya dipatuhi dan dilakukan sesuai dengan prosedur yang telah dibuat diantaranya mengenai penampilan sopir, kondisi kendaraan, dan layanan kepada penumpang.

2. Kesopanan dan keramahan (Tabligh)
Tabligh artinya komunikatif dan argumentatif. Kesopanan dan keramahan merupakan inti dalam memberikan pelayanan. Seperti tertera dalam Alquran Surat Al Ahzab Ayat 70-71:

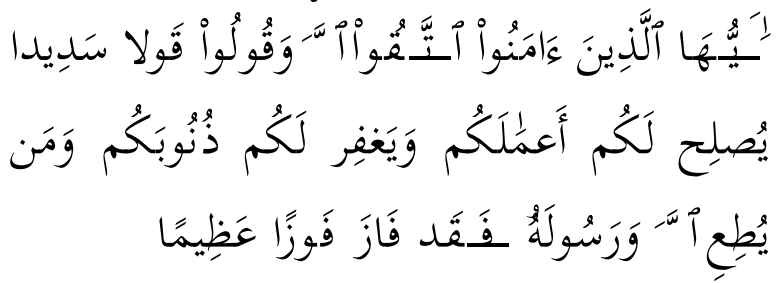

"Hai orang-orang yang beriman, bertakwalah kamu kepada Allah dan katakanlah perkataan yang benar, niscaya Allah memperbaiki bagimu amalanamalanmu dan mengampuni bagimu dosadosamu. Dan barangsiapa mentaati Allah dan Rasul-Nya, maka sesungguhnya ia telah mendapat kemenangan yang besar".

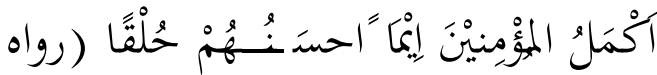

$$
\begin{aligned}
& \text { (النزمذى) }
\end{aligned}
$$

"Paling sempurna iman seseorang muslim adalah paling baik budi pekertinya”. (HR. Tirmidzi)

Dalam pelayanan sopir Gojek Online tingkat kesopanan dan keramahan masih kurang maksimal hal ini terkait adanya konsumen yang mengatakan, kurangnya komunikatif antara sopir dan konsumen, kurangnya implementasi dalam senyum, salam dan sapa.

3. Jujur (Sidiq)

Jujur yaitu tidak pernah berdusta dalam melakukan suatu kegiatan transaksi. Jujur juga merupakan kesesuaian antar berita. Seperti tertera dalam Alquran Surat Az Zumar Ayat 33 :

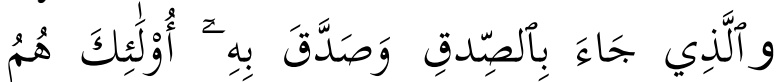

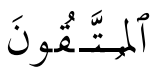

"Dan orang yang membawa kebenaran (Muhammad) dan membenarkannya, mereka itulah orang-orang yang bertakwa"

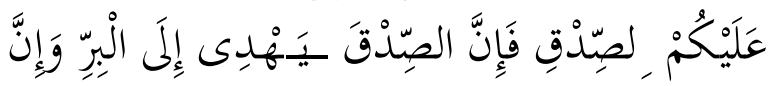

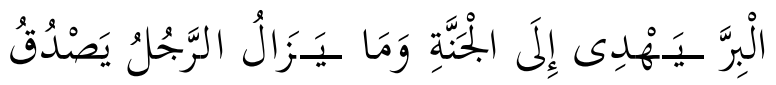

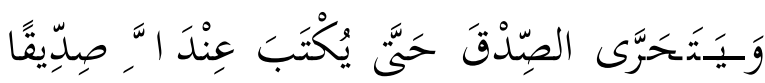

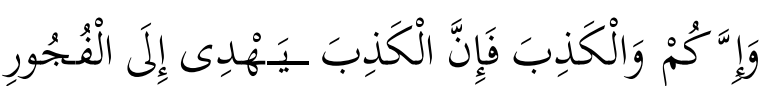




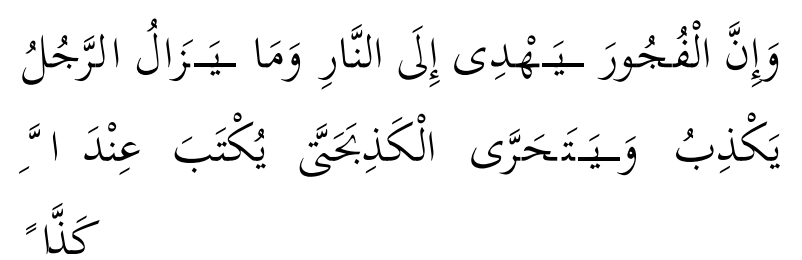

"Hendaklah kalian senantiasa berlaku jujur, karena sesungguhnya kejujuran akan megantarkan pada kebaikan dan sesungguhnya kebaikan akan mengantarkan pada surga. Jika seseorang senantiasa berlaku jujur dan berusaha untuk jujur, maka dia akan dicatat di sisi Allah sebagai orang yang jujur. Hati-hatilah kalian dari berbuat dusta, karena sesungguhnya dusta akan mengantarkan kepada kejahatan dan kejahatan akan mengantarkan pada neraka. Jika seseorang sukanya berdusta dan berupaya untuk berdusta, maka ia akan dicatat di sisi Allah sebagai pendusta. (Abdullah bin Mas'ud radhiyallahu 'anhu)

Yang dimaksud orang yang membawa kebenaran adalah orang yang selalu jujur di setiap perkataan, perbuatan, dan keadaannya.

Dalam pelayanan sopir Gojek Online tingkat kejujuran masih ada yang kurang maksimal hal ini terkait adanya sopir yang masih menggunakan akun orang lain, jadi foto sopir dan plat nomor yang ada pada aplikasi berbeda dengan foto dan plat nomor sopir yang datang aktual.

4. Amanah

Amanah yang berarti bertanggung jawab atas semua pkerjaan yang dilakukan.

Seperti tertera dalam Alquran Surat Almu'minun Ayat 8 :

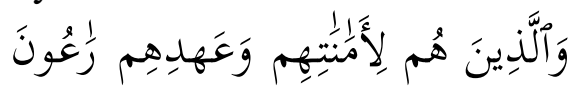

"Dan orang-orang yang memelihara amanatamanat (yang dipikulnya) dan janjinya”.

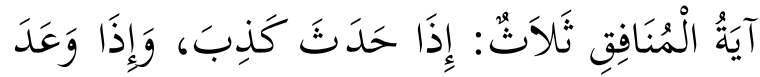

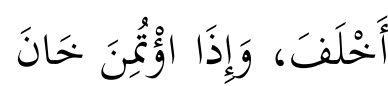

"Tanda-tanda orang munafik ada tiga; jika berbicara ia berbohong, jika berjanji ia ingkar, dan jika diberi amanat ia berkhianat." (Muttafaq Alaihi).

Dalam pelayanan sopir Gojek Online mengenai rasa tanggung jawab yang dimiliki sopir. Dalam hal ini sopir Go-Jek sudah memiliki rasa tanggung jawab dengan mengantarkan pelanggan ke tempat yang dituju dengan selamat, akan tetapi ada juga sopir yang terkadang membatalkan orderan secara sepihak tanpa komunikasi kepada konsumen.

\section{PENUTUP}

\section{A. Kesimpulan}

Hasil dari penelitian ini adalah pelayanan merupakan suatu yang penting dalam bidang bisnis khususnya bidang jasa. Begitu pula PT. Gojek Online Indonesia mempunyai Standar Operasional Prosedur khusus driver dalam melayani konsumen baik itu terkait dengan penampilan sopir masih belum sesuai diantanya banyak sopir yang masi memodifikasi jaket, kondisi kendaraan masih belum sesuai diantaranya masih ada penginjak motor yang rusak dan cara melayani konsumen juga masih belum sesuai karena masih banyak sopir yang memperlakukan konsumen dengan tidak ramah.

Pelayanan driver Gojek Online ditinjau dari Perspektif Islam berdasarkan teori Perspektif Islam ala Rosulullah yang menyangkut empat aspek yaitu Shidiq, Fhatanah, Amanah, Tabligh masih belum sepenuhnya sesuai. Diantaranya Shidiq bahwa masih ada sopir yang memakai akun palsu.

B. Saran

Setelah paparan kesimpulan penelitian di atas, maka ada beberapa saran dari penyusun untuk pengguna akun media sosial Instagram terkhususkan kepada pihak pihak sopir danpihak konsumen dan berikut ini adalah saran saran dari penulis.

1. Bagi para sopir Gojek Online agar dapat mematuhi ataupun memberikan pelayanan sesuai dengan standar operasioanal perusahaan yang telah diterapkan. Bagi sopir Gojek Online agar dapat memberikan pelayan yang sesuai dengan aspek Perspektif islam baik dalam hal kejujuran, profesionalisme, amanah maupun tanggungjawab dalam pekerjaannya yang dilakukannya.

2. Bagi para konsumen agar mampu mengahargai dan memberikan suatu penghargaan baik berupa pemeberian bintang atas pelayanan yang telah diberikan maupun berupa ucapan 


\section{EKSISBANK Vol. 4 No. 1 Juni 2020}

terimakasih untuk sekedar menghargai atas pelayanan sopir Gojek Online.

C. Rekomendasi

Berdasarkan kesimpulan yang telah dipaparkan, maka penulis mengajukan rekomendasi yang dipandang berguna bagi penelitian selanjutnya dan bagi pihak sopirl maupun komsumen:

1. Hasil penelitian menunjukan bahwa pelayanan sopir Gojek Online belum sepenuhnya sesuai dengan etika bisnsis Islam. Maka penulis memberikan rekomendasi kepada sopir Gojek Online agar lebih mengutamakan kejujuran, profesionalisme serta tanggung jawab dalam hal pelayanan. Begitu pun sebaliknya konsumen yang mengargai atas jasa yang telah diberikan sopir Gojek Online.

2. Untuk peneliti selanjutnya, peneliti mengharapkan adanya penelitian yang lebih inovatif serta mendalam mengenai pelayanan maupun mengenai lokasi fokus yang dipilih, sehingga akan memberikan suatu penelitian yang lebih luas serta lebih berkualitas.

\section{DAFTAR PUSTAKA}

Adam, M. (2015). Manajemen Pemasaran Jasa. Alfabeta.

Arikunto, S. (2013). Prosedur Penelitian Suatu Pendekatan Praktek (1st ed.). Rineka Cipta.

Assauri, S. (2015). Manajemen Pemasaran. Raja Grafindo Persada.

Buchari Alma. (2007). Manajemen Pemasaran Dan Pemasaran Jasa. Alfabeta.

Djunaidi, M., Setiawan, E., \& Hariyanto, T. (2006). Analisis Kepuasan Pelanggan Dengan Pendekatan Fuzzy Service Quality Dalam Upaya Peningkatan Kualitas Pelayanan. Jurnal Ilmiah Teknik Industri, 4(3), 139-146.

Fajar Fahrudin, M., \& Yulianti, E. (2015). Pengaruh promosi, lokasi, dan kualitas layanan terhadap keputusan pembelian nasabah Bank Mandiri Surabaya. Journal of Business \& Banking, 5(1), 149. https://doi.org/10.14414/jbb.v5i1.478
Hakim, A. L., Arifin, R., \& Hufron, M. (2018). Pengaruh kualitas sistem informasi, harga, promosi, dan pelayanan terhadap kepuasan pelanggan. 24-34.

Hendryad, S. (2015). Metode Riset Kuantitatif Teori dan Aplikasi Pada Penelitian Bidang Manajemen dan Ekonomi Islam. Prenademedia Group.

Hosang, N., Tumbel, A., Moniharapon, S., Manajemen, J., Ekonomi, F., \& Bisnis, D. (2016). Analisis Pengaruh Kualitas Pelayanan Dan Harga Terhadap Kepuasan Pasien (Studi Kasus Pada Rumah Sakit Siloam Manado) Analysis Effect Of Service Quality And Price To The Patient Satisfaction (Case Study At Siloam Hospital Manado). In Jurnal Berkala Ilmiah Efisiensi (Vol. 16, Issue 01). https://ejournal.unsrat.ac.id/index.php/jbie/ article/view/10625

Ipul. (2019). Pelayalanan Driver Gojek.

Moleong, L. J. (2017). Metodologi Penelitian Kualitatif. Remaja Rosdakarya.

Mujariyah, M. (Mujariyah), \& Ruzikna, R. (Ruzikna). (2016). Pengaruh Struktur Modal terhadap Kinerja Keuangan (Studi pada Bank Milik Bumn yang Terdaftar di Bursa Efek Indonesia Tahun 2008-2014). Jurnal Online Mahasiswa Fakultas Ilmu Sosial Dan Ilmu Politik Universitas Riau, $3(2), 1-15$.

Mutmainah, D., \& Kamaluddin. (2019). Peran Guru Pendidikan Pancasila Dan Kewarganegaraan Dalam Membentuk Sikap Dan Kepribadian Siswa. CIVICUS : Pendidikan-Penelitian-Pengabdian

Pendidikan Pancasila Dan Kewarganegaraan, $6(2), \quad 44$. https://doi.org/10.31764/civicus.v6i2.673

Nuha, U. (2016). Meningkatkan Kualitas Pelayanan Perpustakaan Dengan Pendekatan Bilingual. LIBRARIA: Jurnal Perpustakaan, 2(1). https://doi.org/10.21043/LIBRARIA.V2I1.1190

Rully Tri Indriastuti, U. (2010). Pengaruh Dimensi Kualitas Pelayanan Jasa terhadap 
EKSISBANK Vol. 4 No. 1 Juni 2020

Kepuasan Nasabah. Jurnal Ekonomi Dan Kewirausahaan, 10(2), 23412.

Sugiyono. (2017). Metode Penelitian Kuantitatif, Kualitatif, dan $R \& D$. Alfabeta.

Sula, M. S., \& Kartajaya, H. (2006). Syariah Marketing. Mizan.

Syahbuddin, A. (2018). Analisis Prilaku Konsumen Terhadap Pembelian Keputusan Terhadap Pembelian Kendaraan Bermotor. Universitas Islam Negeri Raden Intan Lampung.

Tampi, A. G. C., Kawung, E. J. R., \& Tumiwa, J. W. (2016). Dampak Pelayanan Badan Penyelenggara Jaminan Sosial Kesehatan Terhadap Masyarakat Di Kelurahan Tingkulu. Acta Diurna, 5(1), 40-52. file:///E:/11717-23371-1-SM.pdf

Wardana, M., \& Ariyanto, D. (2016). Pengaruh Gaya Kepemimpinan Transformasional, Objektivitas, Integritas Dan Etika Auditor Terhadap Kualitas Audit. E-Jurnal Akuntansi, 14(2), 948-976. 